
\title{
25 Research Soure \\ Real-time PCR Biochip for On-Site Detection of Coxiella Burnetii in Ticks
}

\section{A-Tai Truong}

Animal and Plant Quarantine Agency

\section{Bo-Ram Yun}

Animal and Plant Quarantine Agency

Jiyeon Lim

Animal and Plant Quarantine Agency

\section{Subin Min}

Animal and Plant Quarantine Agency

\section{Mi-Sun Yoo}

Animal and Plant Quarantine Agency

\section{Soon-seek Yoon}

Animal and Plant Quarantine Agency

\section{Young-Min Yun}

Jeju National University

Jong-Taek Kim

Kangwon National University

\section{Yun Sang Cho ( $\square$ choys@korea.kr)}

Animal and Plant Quarantine Agency https://orcid.org/0000-0003-1346-7067

\section{Research}

Keywords: Coxiella burnetii, Q fever, Asian longhorned tick, Haemaphysalis longicornis, tick-borne diseases, on-site detection

Posted Date: February 11th, 2021

DOl: https://doi.org/10.21203/rs.3.rs-198104/v1

License: (c) (i) This work is licensed under a Creative Commons Attribution 4.0 International License. Read Full License

Version of Record: A version of this preprint was published at Parasites \& Vectors on May 6th, 2021. See the published version at https://doi.org/10.1186/s13071-021-04744-z. 


\section{Abstract}

Background: Q fever, a zoonosis caused by Coxiella burnetii, has adverse effects on public health. Ticks are the natural reservoirs of $C$. burnetii and they contribute to the transmission of the pathogen. A tool for rapid, sensitive, and accurate detection of $C$. burnetii from ticks is important for the prevention of $\mathrm{Q}$ fever.

Methods: Ultra-rapid real-time PCR (UR-qPCR) as a chip-based real-time PCR system was developed for the detection of $C$. burnetii from ticks. The UR-qPCR system was established and evaluated for the rapidity, sensitivity, and specificity of $C$. burnetii detection.

Results: $C$. burnetii was detected using UR-qPCR from 5,644 larval, nymphal, and adult ticks from 408 pools collected from livestock and epidemiologically linked environments in two provinces, Gangwon and Jeju, in Korea. Ticks from three species were identified; Haemaphysalis longicornis accounted for the highest number, present in 333 of 408 pools (81.62\%), followed by Haemaphysalis flava in 62 pools (15.19\%) and Ixodes nipponensis in 13 pools (3.19\%). The rapidity and sensitivity of PCR detection was demonstrated with the sufficient amplification and detection of approximately 56 copies of $C$. burnetii DNA with only 20 min of PCR amplification. The kappa value for the diagnostic agreement between URqPCR and stationary qPCR was in perfect agreement $(p=1)$. PCR detection and sequencing indicated that $C$. burnetii was present in 5 of the 408 pools (1.23\%), in which four pools contained $H$. longicornis and one pool contained $H$. flava. The infection rates of $C$. burnetii in the tick pools collected from Gangwon and Jeju Provinces were $1.70 \%$ and $0.58 \%$, respectively. Phylogenetic analysis indicated a close relationship between the detected $C$. burnetii and those originated from goats, humans, and ticks in different countries, such as USA, France, Germany, and Serbia.

Conclusions: The results of this study could be important for the prevention and control of $\mathrm{Q}$ fever in the two provinces. The UR-qPCR with its features of mobility, sensitivity, and rapidity is helpful for constructing early alert systems in the field for $C$. burnetii in ticks and for alleviating the transmission and economic damage due to $Q$ fever.

\section{Introduction}

Coxiella burnetii is an obligate intracellular bacterium that causes flu-like zoonotic disease [1]. C. burnetii infects a variety of vertebrates and is a key threat to veterinary and human health worldwide [2, 3]. The transmission to humans usually occurs mainly through inhalation of bacteria from contaminated faeces, close contact with livestock, or ingestion of infected animals and animal products $[3,4,5,6,7,8]$.

The reservoirs of $C$. burnetii include birds, mammals, and ticks [1]. More than 40 species of hard and soft ticks are identified as vectors of $C$. burnetii $[9,10]$. Body fluids and faeces of ticks contain a large number of infectious $C$. burnetii [11], as a result, exposure to tick excreta, direct contact with ticks, or tick bite pose potential risks of $C$. burnetii transmission $[10,12]$. However, the possibility of humans being directly infected by tick bites is rare $[13,14,15,16]$. 
Polymerase chain reaction (PCR) and related techniques are widely used as sensitive and specific tools for the detection of $C$. burnetii in ticks, such as conventional PCR [17], restriction fragment length polymorphism (RFLP)-PCR [18, 19], and direct sequencing [20]. The repetitive, transposon-like element, named IS1111, is a specific DNA marker for sensitive detection of $C$. burnetii, in transposon (Trans)-PCR $[5,21]$. PCR-based detection is fast and does not require handling in biosafety level 3 (BL3) cabinets, unlike the isolation of $C$. burnetii.

The cases of $\mathrm{Q}$ fever diagnosed in humans in Korea have rapidly increased in the subsequent years since the first case was recorded in 2006 [22, 23]. However, there is little information on the tick species that carry $C$. burnetii as well as the regions where $C$. burnetii is present in ticks [24]. Therefore, the present study aimed to detect $C$. burnetii in tick samples collected from different regions of Korea. Ultra-rapid realtime PCR (UR-qPCR), a chip-based real-time PCR, was used for the rapid detection of $C$. burnetii from total nucleic acids extracted from tick samples.

\section{Methods}

\section{Tick samples}

In total, 5,644 larval, nymphal, and adult ticks from 408 pools were collected from livestock (cattle and horse) and wild animals (elk, roe deer, raccoon, badger, wild boar, and wild rabbit) from two provinces, Gangwon and Jeju, in Korea between August and November 2019. The 235 pools collected from Gangwon Province were designated as 19M1-19M235, and the 173 samples collected from Jeju Province as $19 \mathrm{~T} 1-19 \mathrm{~T} 173$. Samples were then stored at $-20^{\circ} \mathrm{C}$ for the detection of $C$. burnetii.

\section{Identification of tick species}

The tick species were identified using a stereo microscope, Discovery.V8 (ZEISS, Oberkochen, Germany). The morphological identification was based on a previously established method [25].

\section{Extraction of total nucleic acid}

Total nucleic acids were extracted from tick samples using the Maxwell ${ }^{\circledR}$ RSC Viral Total Nucleic Acid Purification Kit using Maxwell ${ }^{\circledR}$ Instruments (Promega, Madison, WI, USA). One adult tick, 10 nymphs, or 50 larvae were homogenised in a tissue homogeniser using steel beads of diameter $2.381 \mathrm{~mm}$ (SNC, Hanam, Korea). The sample was lysed with $330 \mu$ of lysis buffer in a Precellys 24 Tissue Homogeniser (Bertin Instruments, Montigny-le-Bretonneux, France). The homogenate was incubated at $56^{\circ} \mathrm{C}$ for $10 \mathrm{~min}$ and the following steps were performed using Maxwell ${ }^{\circledR}$ RSC Instrument, according to the manufacturer's instructions. Finally, $50 \mu \mathrm{l}$ of total nucleic acid was obtained from each sample. 


\section{Primers and standard DNA of $C$. burnetii}

C. burnetii was detected by targeting a 295-bp long DNA fragment in the transposase of the insertion sequence (IS) element IS1111a, using the primers Cox-F (5'- GTCTTAAGGTGGGCTGCGTG-3'), and Cox-R (5'-CCCCGAATCTCATTGATCAGC-3'); and probe Cox-TM (FAM-AGCGAACCATTGGTATCGGACGTT-TAMRA) [26]. DNA from the $C$. burnetii strain 493 (Nine Mile Phase I), preserved in our laboratory, was used as the positive control. The PCR product was cloned in the PGEM ${ }^{\circledR}$-T vector system (Promega, Madison, WI, USA).

\section{PCR performance}

UR-qPCR was performed using a GENECHECKER ${ }^{\circledR}$ UF-300 PCR (Genesystem Co., Ltd., Daejeon, Korea) and 2x Rapi: Spec ${ }^{\mathrm{TM}}$ Probe Master mix (Cat. No. 9799100500; Genesystem Co., Ltd.). The reaction mix (10 $\mu \mathrm{l})$ consisted of $0.4 \mu \mathrm{l}(20 \mathrm{pmol})$ of each primer, $0.4 \mu \mathrm{l}(2 \mathrm{pmol})$ of probe, $0.8 \mu \mathrm{ldH}_{2} \mathrm{O}, 5 \mu \mathrm{l}$ PCR premix, and $3 \mu \mathrm{l}$ of sample total nucleic acid. PCR conditions were set as follows: $95^{\circ} \mathrm{C}$ for $30 \mathrm{~s}, 50$ cycles of 95 ${ }^{\circ} \mathrm{C}$ for $5 \mathrm{~s}$, and $60{ }^{\circ} \mathrm{C}$ for $10 \mathrm{~s}$. Detection of $C$. burnetii was carried out in two steps; screening and detection. $C$. burnetii was screened from a pool of five samples, prepared by combining $10 \mu$ of total nucleic acid from each sample. The individual samples from the PCR-positive pooled samples were then reanalysed to identify the exact sample that carried the pathogen.

The performance of the UR-qPCR system was compared to that of CFX96 Touch Real-time PCR Detection System (Bio-Rad, Hercules, CA, USA), by evaluating the amplification for each of the 408 tick pool nucleic acids using the same primers and probe. The $20 \mu \mathrm{l}$ reaction mixture consisted of $1 \mu \mathrm{l}(10 \mathrm{pmol})$ of each primer, $1 \mu \mathrm{l}(5 \mathrm{pmol})$ of probe, $10 \mu \mathrm{L}$ of iQ ${ }^{\mathrm{TM}}$ Supermix as PCR premix (Bio-Rad), $3 \mu$ of DNA template, and $4 \mu \mathrm{l}$ of $\mathrm{ddH}_{2} \mathrm{O}$. PCR conditions were set as follows: $50^{\circ} \mathrm{C}$ for $2 \mathrm{~min}, 95^{\circ} \mathrm{C}$ for $10 \mathrm{~min}, 40$ cycles of $95^{\circ} \mathrm{C}$ for $15 \mathrm{~s}$, and $60^{\circ} \mathrm{C}$ for $30 \mathrm{~s}$.

\section{Sensitivity and specificity of $C$. burnetii UR-qPCR}

To check the sensitivity of UR-qPCR, serial dilutions of $C$. burnetii recombinant DNA template, from $2.8 \times 10^{8}$ to $2.8 \times 10^{0}$ copies, were used for PCR in triplicate to identify the minimum copy number at which the amplification was stable.

To evaluate the specificity of UR-qPCR for $C$. burnetii, DNA from five other tick-borne pathogens (Anaplasma phagocytophilum, Ehrlichia chaffeensis, Ehrlichia canis, Toxoplasma gondii, Borrelia burgdorferi) were tested with $C$. burnetii-specific primers and probe under the same PCR conditions.

\section{Sequencing and phylogenetic analysis}


The accuracy of UR-qPCR for $C$. burnetii detection was confirmed through sequencing of the PCR products using Cox-F/R primers. Phylogenetic analysis of the $C$. burnetii sequence was performed using a 687 bp DNA fragment of the IS1111 transposon gene, which was amplified using the primer pair Trans 1 (5'-TATGTATCCACCGTAGCCAGTC-3')/Trans 2 (5'-CCCAACAACACCTCCTTATTC-3') [27, 28]. The sequences were compared to the available $C$. burnetii sequences in NCBI using the Basic Local Alignment Search Tool (BLAST). Consensus sequences were aligned using the Clustal X2 program [29], overhanging ends were trimmed using BioEdit 7.2 [30], and a maximum likelihood phylogenetic tree was created using MEGA7 [31], bootstrapping 1000 times.

\section{Results}

\section{Sensitivity and specificity of $C$. burnetii specific UR-qPCR}

UR-qPCR could stably detect $C$. burnetii DNA at $5.6 \times 10^{1}$ copies with a Ct of less than 40 (Fig. $1 \mathrm{a}$ ). The linear regression representing the relationship between initial DNA copy number and $\mathrm{Ct}$ from triplicate PCR reactions was determined by $y=-3.1797 x+45.079 ; \mathrm{R}^{2}=0.9977$, where $y$ and $x$ are Ct value and $\log _{10}$ DNA copy number, respectively (Fig. 1b). The amplification efficiency calculated from the slope of the standard curve $\left(\mathrm{E}=10^{(-1 / \text { slope })}-1\right)$ was $106.30 \%$.

The specificity of the UR-qPCR system for $C$. burnetii detection was confirmed by the lack of cross detection of any of the five other tick-borne pathogens (Fig. 2). Therefore, the UR-qPCR system could be a potential molecular tool for the rapid, sensitive, and specific detection of $C$. burnetii from ticks and for the diagnosis of $Q$ fever.

\section{Infection rate of $\boldsymbol{C}$. burnetii in tick samples}

Ticks from 408 pools were evaluated; the major species was Haemaphysalis longicornis (Asian longhorned tick), present in 333 pools (81.62\%), followed by H. flava, in 62 pools (15.19\%), and Ixodes nipponensis (Japanese hard tick), in 13 pools (3.19\%). I. nipponensis was observed only in the pools from Gangwon Province. Five of the 408 tick pools (1.23\%) carried C. burnetii, in which four pools originated from wild animals and epidemiologically linked environments in Gangwon Province (19M22, 19M42, 19M73, and 19M88) and one pool (19T112) was collected from the cattle in Jeju Province (Table 1).

The rate of $C$. burnetii infection was at $1.20 \%$ (4/333 pools), $1.61 \%$ ( $1 / 62$ pools), and $0 \%$ ( $0 / 13$ pools) in $H$. longicornis, H. flava, and I. nipponensis, respectively. C. burnetii infection was detected in the larval and adult stages of $H$. longicornis at $2.63 \%$ (2/76 pools) and $0.87 \%$ (2/230 pools), respectively, however, only in the adult stage of $H$. flava at $2.70 \%$ (1/37 pools) (Table 2$)$.

The accuracy of $C$. burnetii detection in UR-qPCR was consistent with that of conventional real-time PCR (qPCR; CFX96 Touch Real-time PCR; Bio-Rad). The same five tick pools (19M22, 19M42, 19M73, 19M88, 
and 19T112) were positive (Table 1; Fig. 3). The Cohen's kappa coefficient calculated from the results of UR-qPCR and qPCR was $K=1$, indicating a near perfect agreement $(0.81-1.00)$.

\section{Sequencing and phylogenetic analysis}

Sequencing the $295 \mathrm{bp}$ amplicons confirmed the accuracy of detection. The amplicon from the $19 \mathrm{M} 22$, 19M42, 19M73, and 19T112 pools showed 99\% DNA sequence identity with the sequence from $C$. burnetii strain RSA493 (NCBI accession number CP040059); while the sequence from the 19M88 pool showed $100 \%$ identity to the sequence from $C$. burnetii strain BTM90C (NCBI accession number MN025541) (Additional file 1).

The analysis of the $687 \mathrm{bp}$ fragment showed homologies ranging from 97.43 to $99.85 \%$ to the sequences of $C$. burnetii in NCBI. The detected $C$. burnetii was closely related to and clustered with strains originated from ticks, goats, and humans in the USA, France, Germany, and Serbia, on the phylogenetic tree (Fig. 4).

\section{Discussion}

A chip-based PCR system, UR-qPCR, was introduced in this study for the rapid detection of the tick-borne $\mathrm{Q}$ fever pathogen. The UR-qPCR system is rapid, requiring approximately $20 \mathrm{~min}$ for 50 cycles, compared to the approximately $1 \mathrm{~h}$ and 30 min required for the other PCR systems compared in this study. In addition, targeting IS1111, a multi-copy element in $C$. burnetii [26, 32], increases the sensitivity of the URqPCR system. It is believed that the use of IS1111 is limited by its presence in Coxiella-like bacteria (CLB) [33]; however, we showed that the CLB in ticks does not interfere with the accuracy of $C$. burnetii detection using sequencing.

The diagnosis of Q fever relies mainly on serology [34]. However, serological diagnosis can be unreliable due to the cross-reaction with Bartonella spp., Ehrlichia spp., and Rickettsia spp. [35]. PCR is a useful detection tool for improving the accuracy of a diagnosis [21, 36]; PCR detection of $C$. burnetii in blood was effective in diagnosing $Q$ fever with a sensitivity of approximately $81 \%$ compared to indirect immunofluorescence assay (IFA) [37]. Therefore, UR-qPCR could be used for on-site conformational diagnosis of $\mathrm{Q}$ fever, for the prompt control of milk, blood, or serum samples.

Detection of $C$. burnetii using loop-mediated isothermal amplification (LAMP) assay [38, 39] is rapid and comparable to real-time PCR. The positive detection is based on change of colour in the reaction mix after 30 min incubation. However, the sensitivity of the colorimetric LAMP assay is only $93.75 \%$ compared to that of real-time PCR. Therefore, the UR-qPCR proposed in this study has the advantages of being rapid, with less than 20 min reaction time, and sensitive, at $100 \%$ sensitivity compared to other realtime PCR systems. The UR-qPCR and the crude DNA preparation [39] together will take less than 30 min for the detection of $C$. burnetii on-site. 
There is only one previous report of $H$. longicornis sample, from Cheongju city in Chungcheongbuk Province in Korea, harbouring $C$. burnetii [40]. However, this study revealed that two $(H$. longicornis and $H$. flava) of the three prevalent tick species (H. longicornis, H. flava, and I. nipponensis) [41] in two provinces (Gangwon and Jeju) harbour the Q fever pathogen. C. burnetii was detected in tick samples from wild animals, livestock, and grasslands with one and four pools in Jeju and Gangwon Provinces, respectively, although no case of $Q$ fever in humans has been recorded in Jeju Province [22]. These provinces have a high risk of $C$. burnetii transmission through the ticks harbouring the pathogen and parasitizing cattle.

\section{Conclusions}

A rapid real-time $P C R$ assay was developed for the detection of the $Q$ fever pathogen, $C$. burnetii, in tick species collected from two provinces in Korea. The rapidity and accuracy of this PCR system was evaluated. The automated nucleic acid isolation system used in this study minimized the exposure to living bacteria in tick, which could pose a risk of $C$. burnetii infection during the sample DNA preparation. C. burnetii was detected in two tick species ( $H$. longicornis and $H$. flava), which are parasites in wild animals and from the grasslands in Gangwon Province, and in $\mathrm{H}$. longicornis from cattle in Jeju Province. This information is important for the prevention of Q fever, particularly in Jeju Province, where no case of infection in humans has been recorded.

\section{Abbreviations}

IS1111: Insertion sequence 1111; CLB: Coxiellatike bacteria; KDCA: Korea Disease Control and Prevention Agency; UR-qPCR: Ultra-rapid real-time polymerase chain reaction; RFLP: Restriction fragment length polymorphism; Ct: Cycle threshold; LAMP: Loop-mediated isothermal amplification.

\section{Declarations}

\section{Acknowledgements}

We would like to thank the Brucellosis OIE Reference Laboratory in Animal and Plant Quarantine Agency in the Republic of Korea for kindly helping with the preparation of the standard DNA of Coxiella burnetii.

\section{Authors' contributions}

The study was designed by YSC, B-RY, and A-TT. A-TT, JL, SM, YMY, and J-TK performed the field and laboratory tests. YSC supervised the study. A-TT, B-RY, M-SY, SY, and YSC analysed the data. A-TT and YSC wrote the manuscript. All authors reviewed and approved the final manuscript for publication.

\section{Funding}

This study was supported by the Animal and Plant Quarantine Agency (Grant number B-1543081-202022-03). 
Availability of data and materials

All data generated or analysed during this study are included in this published article and Additional file 1: Table S1.

\section{Ethics approval and consent to participate}

Not applicable

\section{Consent for publication}

All the authors consent to publication.

\section{Competing interests}

The authors declare that they have no competing interests.

\section{References}

1. Weiss E, Moulder JW. Order I Rickettsiales, Gieszczkiewicz 1939. In: Krieg NR, Holt JG, editors. Bergey's manual of systematic bacteriology. Baltimore, MD: Williams \& Wilkins; 1984. p. 687-703.

2. Lang GH. Coxiellosis (Q fever) in animals. In: Marrie TJ, editor. Q fever (1) The Disease. CRC Press; 1990. p. 23-48.

3. Maurin M, Raoult D. Q fever. Clin Microbiol Rev. 1999;12(4):518-53.

4. Cutler SJ, Bouzid M, Cutler RR. Q fever. J Infect. 2007;54(4):313-8.

5. Fard SN, Khalili M. PCR-detection of Coxiella burnetii in ticks collected from sheep and goats in Southeast Iran. Iran J Arthropod Borne Dis. 2011;5(1):1-6.

6. Sprong H, Tijsse-Klasen E, Langelaar M, De Bruin AD, Fonville M, Gassner F, et al. Prevalence of Coxiella burnetii in ticks after a large outbreak of Q Fever. Zoonoses Public Health. 2012;59(1):6975.

7. Wardrop NA, Thomas LF, Cook EAJ, de Glanville WA, Atkinson PM, Wamae CN, et al. The seroepidemiology of Coxiella burnetii in humans and cattle, western Kenya: evidence from a crosssectional study. PLOS Negl Trop Dis. 2016;10(10):e0005032.

8. Woldehiwet Z. Q fever (coxiellosis): Epidemiology and pathogenesis. Res Vet Sci. 2004;77(2):93-100.

9. Babudieri B. Q fever: a zoonosis. Adv Vet Sci. 1959;5:81-154.

10. Duron O, Sidi-Boumedine K, Rousset E, Moutailler S, Jourdain E. The Importance of ticks in Q Fever transmission: what has (and has not) been demonstrated? Trends Parasitol. 2015;31(11):536-52.

11. Philip CB. Observations on experimental Q fever. J Parasitol. 1948;34(6):457-64.

12. Norlander LQ. Microbes Infect. 2000;2(4):417-24. 
13. Dubourg G, Socolovschi C, Del Giudice P, Fournier PE, Raoult D. Scalp eschar and neck lymphadenopathy after tick bite: an emerging syndrome with multiple causes. Eur J Clin Microbiol Infect Dis. 2014;33(8):1449-56.

14. Eklund CM, Parker RR, Lackman DB. A case of Q fever probably contracted by exposure to ticks in nature. Public Health Rep. 1947;62(39):1413-6.

15. Nett RJ, Book E, Anderson AD. Q Fever with unusual exposure history: a classic presentation of a commonly misdiagnosed disease. Case Rep Infect Dis. 2012;2012:916142.

16. Pacheco RC, Echaide IE, Alves RN, Beletti ME, Nava S, Labruna MB. Coxiella burnetii in ticks, Argentina. Emerg Infect Dis. 2013;19(2):344-6.

17. Rehácek J. Epidemiology and significance of Q Fever in Czechoslovakia. Zentralbl Bakteriol Mikrobiol Hyg A. 1987;267(1):16-9.

18. Çapin A, Emre G, Canpolat Z, Vatansever S, Düzgün Y, Ali A. Detection of Coxiella burnetii from ticks by polymerase chain reaction and restriction fragment length polymorphism. Ank Univ Vet Fak Derg. 2013;60(4):263-8.

19. Spitalská E, Kocianová E. Detection of Coxiella burnetii in ticks collected in Slovakia and Hungary. Eur J Epidemiol. 2003;18(3):263-6.

20. Bernasconi MV, Casati S, Péter O, Piffaretti JC. Rhipicephalus ticks infected with Rickettsia and Coxiella in southern Switzerland (Canton Ticino). Infect Genet Evol. 2002;2(2):111-20.

21. Vaidya VM, Malik SVS, Kaur S, Kumar S, Barbuddhe SB. Comparison of PCR, immunofluorescence assay, and pathogen isolation for diagnosis of Q fever in humans with spontaneous abortions. J Clin Microbiol. 2008;46(6):2038-44.

22. Korea Disease Control and Prevention Agency (KDCA): Disease surveillance statistics. [cited 28 Jan 2021]. Retrieved from: http://www.cdc.go.kr/board/board.es? mid=a30501000000\&bid=0031\&list_no=711880\&act=view; 2021: Public Health Weekly Report 14 (4).

23. Kwak W, Chu H, Hwang S, Park JH, Hwang KJ, Gwack J, et al. Epidemiological Characteristics of Serologically Confirmed Q Fever Cases in South Korea, 2006-2011. Osong Public Health Res Perspect. 2013;4(1):34-8.

24. Im JH, Baek JH, Durey A, Kwon HY, Chung MH, Lee JS. Current status of tick-borne diseases in South Korea. Vector Borne Zoonotic Dis. 2019;19(4):225-33.

25. Yamaguti N, Tipton VJ, Keegan HL, Toshioka S. Ticks of Japan, Korea, and the Ryukyu islands. Brigham Young Univ Sci Bull Biol Ser. 1971;15(1):1-226.

26. Klee SR, Tyczka J, Ellerbrok H, Franz T, Linke S, Baljer G, et al. Highly sensitive real-time PCR for specific detection and quantification of Coxiella burnetii. BMC Microbiol. 2006;6:2.

27. Hoover TA, Vodkin MH, Williams JC. A Coxiella burnetii repeated DNA element resembling a bacterial insertion sequence. J Bacteriol. 1992;174(17):5540-8. 
28. Kilicoglu Y, Cagirgan AA, Serdar G, Kaya S, Durmaz Y, Gur Y. Molecular investigation, isolation and phylogenetic analysis of Coxiella burnetii from aborted fetus and ticks. Comp Immunol Microbiol Infect Dis. 2020;73:101571.

29. Larkin MA, Blackshields G, Brown NP, Chenna R, McGettigan PA, McWilliam H, et al. Clustal W and Clustal X version 2.0. Bioinformatics. 2007;23(21):2947-8.

30. Hall TA. BioEdit: a user-friendly biological sequence alignment editor and analysis program for Windows 95/98NT. Nucl Acids Symp Ser. 1999;41:95-8.

31. Kumar S, Stecher G, Tamura K. MEGA7: Molecular evolutionary genetics analysis version 7.0 for bigger datasets. Mol Biol Evol. 2016;33(7):1870-4.

32. de Souza Ribeiro Mioni M, Ribeiro BLD, Peres MG, Teixeira WSR, Pelícia VC, Motta RG, et al. Real-time quantitative PCR-based detection of Coxiella burnetii in unpasteurized cow's milk sold for human consumption. Zoonoses Public Health. 2019;66(6):695-700.

33. Sahu R, Rawool DB, Vinod VK, Malik SVS, Barbuddhe SB. Current approaches for the detection of Coxiella burnetii infection in humans and animals. J Microbiol Methods. 2020;179:106087.

34. Anderson A, Bijlmer H, Fournier PE, Graves S, Hartzell J, Kersh GJ, et al. Diagnosis and management of Q Fever - United States, 2013: recommendations from CDC and the Q Fever working group. MMWR Recomm Rep. 2013;62(RR-3):1-30.

35. Graham JV, Baden L, Tsiodras S, Karchmer AW. Q fever endocarditis associated with extensive serological cross-reactivity. Clin Infect Dis. 2000;30(3):609-10.

36. Zhang GQ, Nguyen SV, To H, Ogawa M, Hotta A, Yamaguchi T, et al. Clinical evaluation of a new PCR assay for detection of Coxiella burnetii in human serum samples. J Clin Microbiol. 1998;36(1):7780.

37. Bae M, Jin CE, Park JH, Kim MJ, Chong YP, Lee SO, et al. Diagnostic usefulness of molecular detection of Coxiella burnetii from blood of patients with suspected acute Q fever. Medicine (Baltimore). 2019;98(23):e15724.

38. Das DP, Malik SVS, Sahu R, Yadav JP, Rawool DB, Barbuddhe SB. Loop-mediated isothermal amplification assay for detection of Coxiella burnetii targeting the com 1 gene. J Microbiol Methods. 2018;155:55-8.

39. Sheikh N, Kumar S, Sharma HK, Bhagyawant SS, Thavaselvam D. Development of a rapid and sensitive colorimetric loop-mediated isothermal amplification assay: a novel technology for the detection of Coxiella burnetii from minimally processed clinical samples. Front Cell Infect Microbiol. 2020;10:127.

40. Lee JH, Park HS, Jang WJ, Koh SE, Park TK, Kang SS, et al. Identification of the Coxiella sp. detected from Haemaphysalis longicornis ticks in Korea. Microbiol Immunol. 2004;48(2):125-30.

41. Chae JB, Cho YS, Cho YK, Kang JG, Shin NS, Chae JS. Epidemiological investigation of tick species from near domestic animal farms and cattle, goat, and wild boar in Korea. Korean J Parasitol. 2019;57(3):319-24. 


\section{Tables}

Table 1 Infection rate of Coxiella burnetii in ticks collected from Jeju and Gangwon Provinces in 2019 


\begin{tabular}{|c|c|c|c|c|c|}
\hline \multirow[t]{2}{*}{ Province } & \multirow[t]{2}{*}{ Species } & \multirow[t]{2}{*}{ Stage } & \multirow{2}{*}{$\begin{array}{l}\text { No. of ticks (No. of tested } \\
\text { pools) }\end{array}$} & \multicolumn{2}{|c|}{ Positive pools (\%) } \\
\hline & & & & $\begin{array}{l}\text { UR- } \\
\text { qPCR }\end{array}$ & qPCR \\
\hline \multirow[t]{12}{*}{ Gangwon } & \multirow{4}{*}{$\begin{array}{l}\text { H. } \\
\text { longicornis }\end{array}$} & Larva & $2,764(53)$ & $1(1.89)$ & $1(1.89)$ \\
\hline & & Nymph & $50(14)$ & 0 & 0 \\
\hline & & Adult (male) & $38(15)$ & 0 & 0 \\
\hline & & $\begin{array}{l}\text { Adult } \\
\text { (female) }\end{array}$ & $240(122)$ & $2(1.64)$ & $2(1.64)$ \\
\hline & \multirow[t]{4}{*}{ H. flava } & Larva & 0 & 0 & 0 \\
\hline & & Nymph & $93(7)$ & 0 & 0 \\
\hline & & Adult (male) & $28(5)$ & $\begin{array}{l}1 \\
(20.00)\end{array}$ & $\begin{array}{l}1 \\
(20.00)\end{array}$ \\
\hline & & $\begin{array}{l}\text { Adult } \\
\text { (female) }\end{array}$ & $10(6)$ & 0 & 0 \\
\hline & \multirow{4}{*}{$\begin{array}{l}\text { I. } \\
\text { nipponensis }\end{array}$} & Larva & 0 & 0 & 0 \\
\hline & & Nymph & $16(2)$ & 0 & 0 \\
\hline & & Adult (male) & $3(1)$ & 0 & 0 \\
\hline & & $\begin{array}{l}\text { Adult } \\
\text { (female) }\end{array}$ & $30(10)$ & 0 & 0 \\
\hline \multirow[t]{8}{*}{ Jeju } & \multirow{4}{*}{$\begin{array}{l}\text { H. } \\
\text { longicornis }\end{array}$} & Larva & $1,470(23)$ & $1(4.35)$ & $1(4.35)$ \\
\hline & & Nymph & $158(13)$ & 0 & 0 \\
\hline & & Adult (male) & $99(33)$ & 0 & 0 \\
\hline & & $\begin{array}{l}\text { Adult } \\
\text { (female) }\end{array}$ & $208(60)$ & 0 & 0 \\
\hline & \multirow[t]{4}{*}{ H. flava } & Larva & 0 & 0 & 0 \\
\hline & & Nymph & 368 (18) & 0 & 0 \\
\hline & & Adult (male) & $30(8)$ & 0 & 0 \\
\hline & & $\begin{array}{l}\text { Adult } \\
\text { (female) }\end{array}$ & 39 (18) & 0 & 0 \\
\hline Total & & & $5,644(408)$ & $5(1.23)$ & $5(1.23)$ \\
\hline
\end{tabular}

Table 2 Detection rate of Coxiella burnetii from tick species 


\begin{tabular}{|c|c|c|c|c|}
\hline \multirow[t]{2}{*}{ Species } & \multirow[t]{2}{*}{ Stage } & \multirow[t]{2}{*}{ No. of ticks (No. of tested pools) } & \multicolumn{2}{|c|}{ Positive pools (\%) } \\
\hline & & & UR-qPCR & qPCR \\
\hline \multirow[t]{4}{*}{ H. longicornis } & Larva & $4,234(76)$ & $2(2.63)$ & $2(2.63)$ \\
\hline & Nymph & $208(27)$ & 0 & 0 \\
\hline & Adult (male) & $137(48)$ & 0 & 0 \\
\hline & Adult (female) & $448(182)$ & $2(1.10)$ & $2(1.10)$ \\
\hline \multirow[t]{4}{*}{ H. flava } & Larva & 0 & 0 & 0 \\
\hline & Nymph & $461(25)$ & 0 & 0 \\
\hline & Adult (male) & $58(13)$ & $1(7.69)$ & $1(7.69)$ \\
\hline & Adult (female) & $49(24)$ & 0 & 0 \\
\hline \multirow[t]{4}{*}{ I. nipponensis } & Larva & 0 & 0 & 0 \\
\hline & Nymph & $16(2)$ & 0 & 0 \\
\hline & Adult (male) & $3(1)$ & 0 & 0 \\
\hline & Adult (female) & $30(10)$ & 0 & 0 \\
\hline Total & & $5,644(408)$ & $5(1.23)$ & $5(1.23)$ \\
\hline
\end{tabular}

\section{Figures}

a

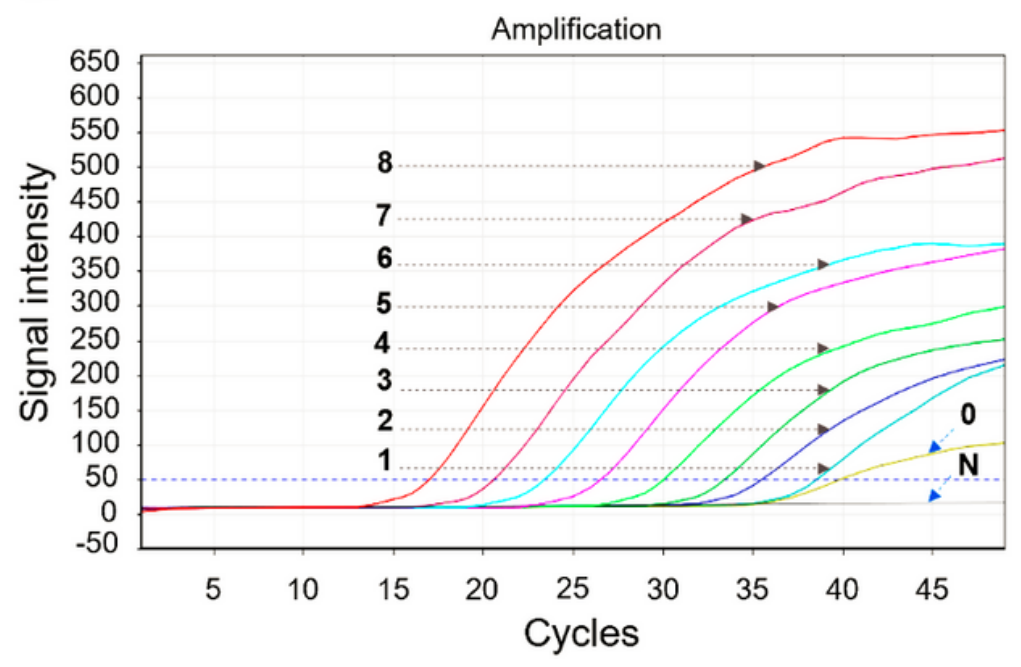

b

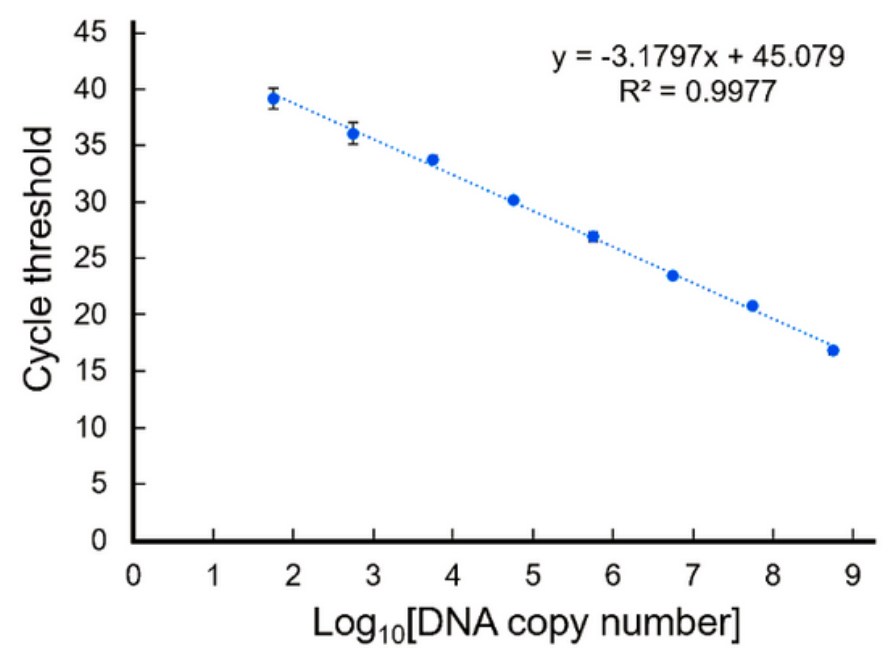

Figure 1

Sensitivity of UR-qPCR for detection of Coxiella burnetii. a The amplification curves indicate the amplification of C. burnetii recombinant DNA, serially diluted from $5.6 \times 108$ to $5.6 \times 100$ copies, denoted by 
numbers 8 to 0 , respectively. " $N$ " is negative control without DNA template. b Standard linear regression graph representing the relationship between initial DNA copy number and Ct value, averaged from PCR reactions performed in triplicate.

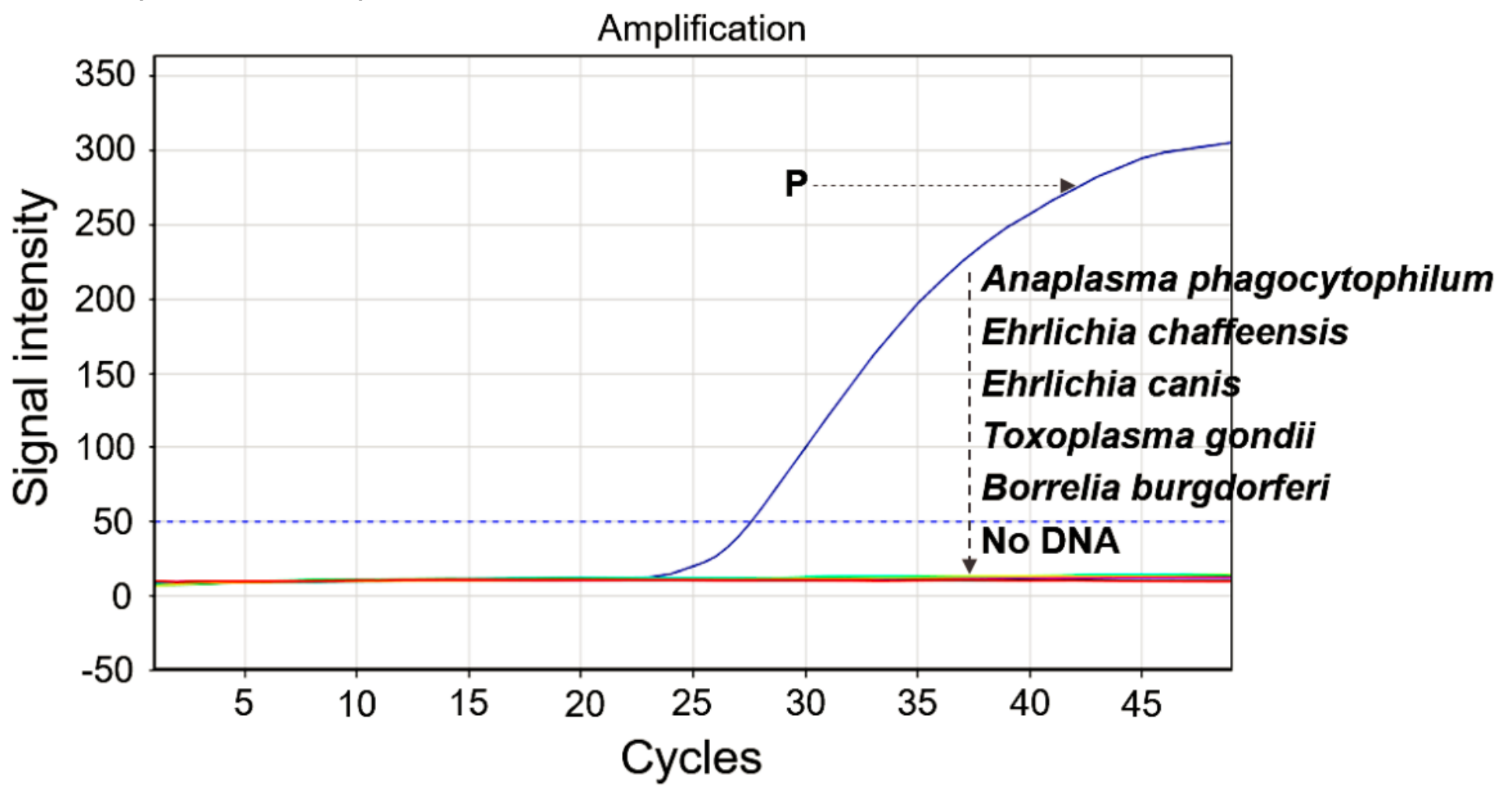

Figure 2

Specificity of UR-qPCR for detection of Coxiella burnetii. The specificity of UR-qPCR for the detection of C. burnetii was confirmed by the lack of amplification from the DNA templates of five other tick-borne pathogens (Anaplasma phagocytophilum, Ehrlichia chaffeensis, Ehrlichia canis, Toxoplasma gondii, Borrelia burgdorferi) and in the negative control, which lacked the DNA template. "P" is the positive control containing 105 copies of $\mathrm{C}$. burnetii recombinant DNA. 
a

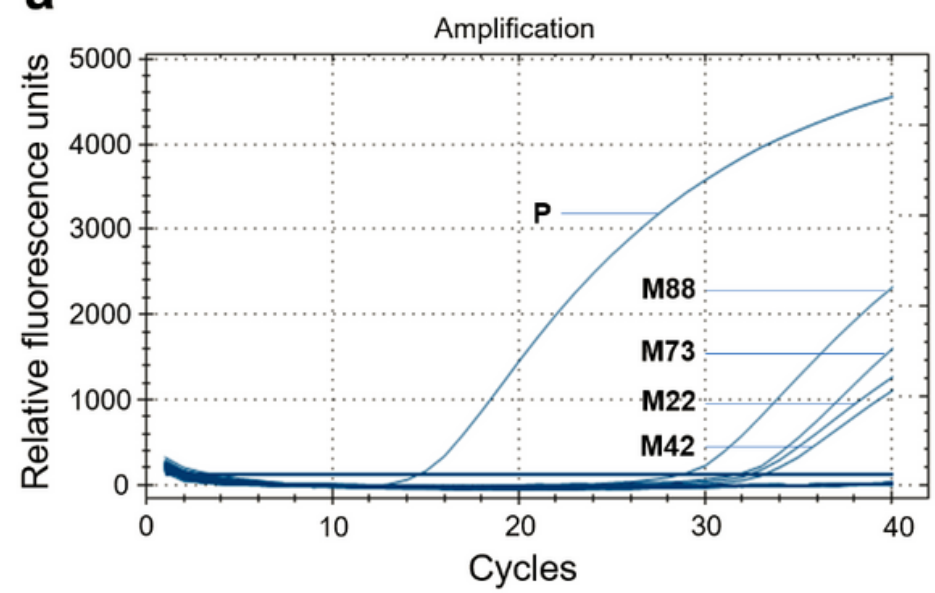

C

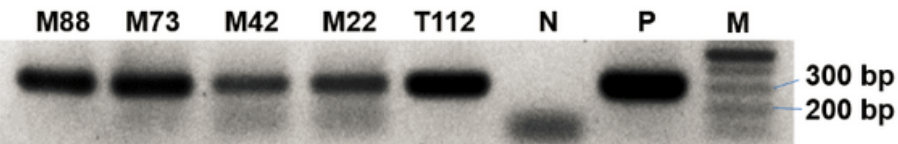

b

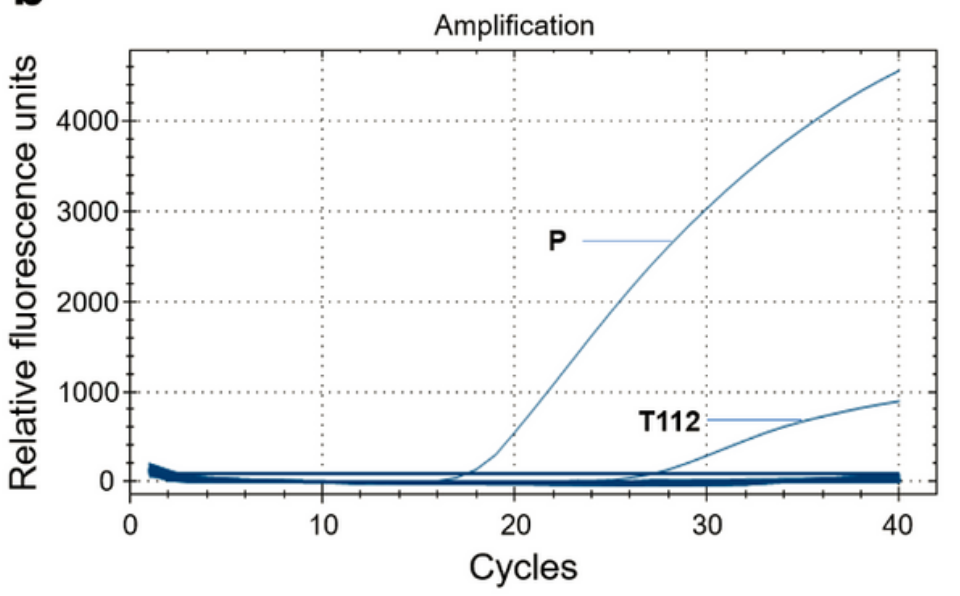

Figure 3

Confirmation of Coxiella burnetii detection from tick samples. Detection curves indicate that the same five tick samples are positive for C. burnetii, when tested using the CFX96 Touch Real-time PCR System (Bio-Rad). a Four samples (19M88, 19M73, 19M42, 19M22) from Gangwon Province, b One sample (19T112) from Jeju Province. " $P$ " is the positive control using C. burnetii recombinant DNA. c Electrophoresis of PCR amplicons (295 bp long) from the five samples (19M88, 19M73, 19M42, 19M22, 19T112) positive for $C$. burnetii. " $P$ " and " $N$ " are the positive control and the negative control, without DNA template, respectively, and " $\mathrm{M}$ " is the 100 bp DNA marker. 


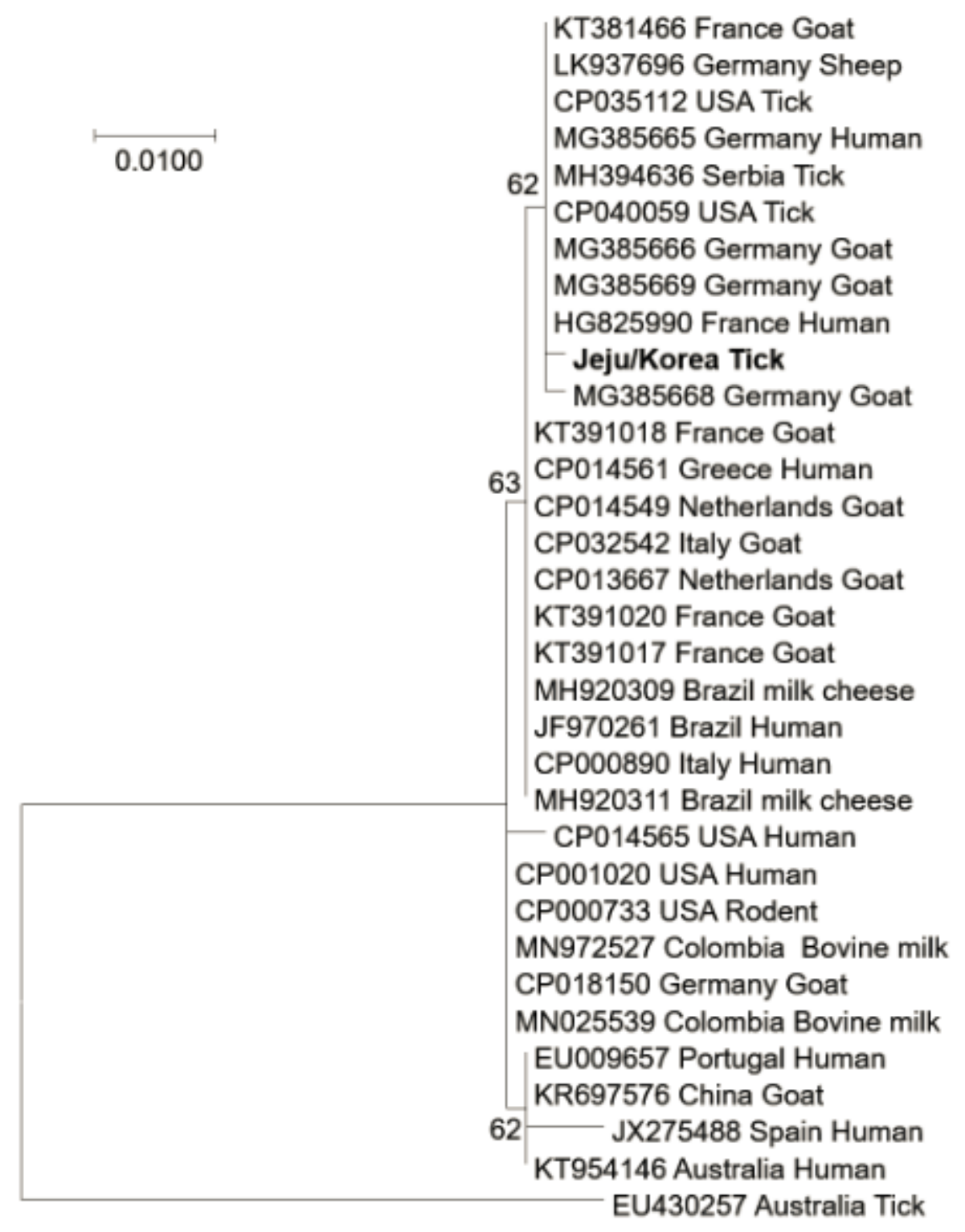

Figure 4

Maximum likelihood phylogenetic tree based on the partial IS1111 nucleotide sequences (643 bp) of Coxiella burnetii from the Republic of Korea and other countries. The sequences were aligned using Clustal X2, edited using BioEdit, and maximum likelihood tree generated using MEGA7 software, bootstrapping 1000 times.

\section{Supplementary Files}

This is a list of supplementary files associated with this preprint. Click to download.

- AdditionalFile.docx

- graphicalabstract.tif 